\title{
Signo Cimarrón: diálogos afro-poético-musicais
}

\author{
Adélcio de Sousa Cruz \\ Universidade Federal de Minas Gerais
}

\author{
La herencia no existe \\ sin un cuerpo-lenguage que la \\ transforme.
}

(PEREIRA, 2005: 23)

igno Cimarrón é o livro de Edimilson de Almeida Pereira que conecta a poesia afro-brasileira com outras praias literárias e musicais banhadas por águas atlânticas. O símbolo do cimarrón significa um ex-escravo que, após fugir do cativeiro, passa a viver de forma solitária ou em pequenas comunidades, denominadas palenques (LUIS, 2005: 9). Esse sucinto e profundo trabalho traça um percurso poético que se movimenta entre os caminhos da rememoração do passado colonial escravista e as vozes que permanecem ecoando interpelações à História, desde o primeiro momento da diáspora africana nas Américas até o presente. O poema de abertura, "Indícios", bem como os versos que escolhi para a epígrafe, já chama a atenção para o grau de dificuldade da empreitada: "Los textos de la memoria esperan lectores, / el desafío es escoger la frase que nos presenta unos a los otros" (PEREIRA, 2005: 23). Normalmente, um poema é escrito a partir de uma única "voz" - aquela pertencente ao eu lírico. No entanto, o que se mostra aqui são outras vozes agregadas a esse indivíduo poético, permitindo ao leitor se comunicar ora com os vestígios legados ao completo esquecimento, ora com aqueles silenciados no porão durante a viagem entre a África e as Américas.

A escolha pela língua espanhola opera desejos: entrar em contato com autores e leitores da América hispânica, com atenção especial àqueles de ascendência africana; mesclar-se à tradição da literatura hispânica - inserindo aí outra fala afro-descendente advinda do único país de língua portuguesa 
do continente americano; mostrar o que pode ser interpretado como similar dentre as diversas experiências da diáspora africana nas Américas, através dos diálogos estéticos, sejam estes poéticos e/ou musicais; interrogar de forma crítica e simultânea às heranças culturais e políticas da colonização capitaneada pela península Ibérica a partir do século XVI. Há um fator que deve ser considerado com relação aos desejos. A escolha pelo signo da cimarronage pode ser interpretada de modo metalingüístico, pois o cimarrón se alia ao poeta que se rebela contra o domínio de uma tradição literária apenas eurocêntrica, e, ainda, traz para a cena a figura do griot, quando se aventura a recontar a história silenciada da diáspora africana.

O poema "Signo" possibilita aproximar as instâncias de cimarrón, a de poeta, quando já em seu início indica que o texto, às vezes, se classificaria no âmbito de "una cimarronada", aqui entendida como rebeldia por incorporar o imprescindível elemento da memória ao discurso estético do poema, que flutua entre a fala individual e a coletiva. $\mathrm{O}$ eu lírico insere o griot à condição afro-diaspórica nas Américas através do cimarrón. O poema aponta ainda para o aspecto fugidio desse signo escolhido por Edimilson de Almeida Pereira: "Preso, no dice nada, / libre se esconde en la plaza"(PEREIRA, 2005: 30), que logra se ocultar em pleno espaço público, pois embora seja signo conhecido, seu significado não é estático.

As interpelações não cessam. E estas se inscrevem sem a contaminação do rancor, pois este ali não tem serventia. Os poemas "Ciudades" (idem, p. 34) e "Concierto" (idem, p. 35) abrem a memória como transparentes tabuleiros de xadrez superpostos. No primeiro deles, a concisão aproxima duas cidades pelo nome: Santiago de Cuba, e a outra localizada ao norte da Espanha, Santiago de Compostela. O verso funde dois lugares e suas histórias/memórias, criando nova denominação: "santiago de cuba de compostela". A ausência de letras maiúsculas não lhes reduz a importância, salienta a riqueza de suas diferenças. Quanto ao texto "Concierto", a hereditariedade e o reencontro com as raízes retornam aos "abuelos" (avôs) e às "abuelas" (avós). Ali, o eu lírico exercita outra "cimarronada", e a voz masculina abre uma fissura na página ao enunciado feminino: "pero las mujeres nos preguntan / qué es de la luna y de nosotras / inaugurando las plumas?". A história pede desculpas, nem que seja no poema, "por olvidar a muchos" (idem, p. 35)... 
A releitura das cenas de Rugendas traduz a oportunidade de comparação mnemônica ao público afro-hispânico no que diz respeito à diáspora africana em terras brasileiras. A "linha de cor" (DU BOIS, 1994) é rearranjada com o jogo proposto com as palavras "verde", "azul", "negro" e "branco". Todas elas lançam-se fora da página e no último verso indagam sobre a temporalidade das imagens de violência: se estariam estas últimas locadas no século XIX ou no corrente século XXI.

$O$ vasto repertório do autor permite agrupar num mesmo poema a tradição poético-musical originária da Grécia e sua mitologia - a figura de Orfeu - e músicos afro-americanos de dicção hispânica e inglesa: os afro-latinos Beny Moré, Bola de Nieve e o bluesman John Lee Hooker. Essa confluência de diferentes águas remete à primeira estrofe do poema "Tempestad": "Heredamos la palabra, / usarla prueba / que sobrevivimos" (PEREIRA, 2005: 25), pois coloca à prova intenção estética apenas: há que se lidar com o passado e suas vozes herdadas. Ao cobertor da língua parece sempre faltar extensão para cobrir o "corpo-linguagem", que nunca é monolítico e surpreenderá leitores com os diversos tons de azul e verde, negro e branco do Atlântico oceano.

\section{Referências Bibliográficas}

DU BOIS, William Edward Burghardt. The souls of black folk. The 1903 unabridged text. New York: Dover Publications, 1994.

LUIS, William. Introducción a Signo cimarrón. In: PEREIRA, Edimilson de Almeida. Signo cimarrón. Belo Horizonte: Mazza Edições, 2005. p. 7-19.

PEREIRA, Edimilson de Almeida. Signo cimarrón. Belo Horizonte: Mazza Edições, 2005. $96 \mathrm{p}$. 